\title{
針筋電図における運動単位活動電位（MUAP）の生理と臨床
}

\author{
赤星 和 人*
}

\section{Neurophysiological Feature of MUAP Parameters in Concentric Needle EMG and Its Clinical Use}

\author{
Kazuto Akaboshi*
}

\begin{abstract}
The most commonly used EMG method for daily routine is that obtained with concentric needle electrodes, and a number of parameters have been used to characterize the motor unit action potential (MUAP). It is important to understand the physiological meaning of each parameter and pathology of neuropathic and myopathic disease. Amplitude is measured as maximal peak to peak voltage. It determined by muscle fibers within $0.5 \mathrm{~mm}$ from the electrode, i.e. a few fibers in normal subjects. Reduced amplitude means atrophy of muscle fibers, decreased numbers of the muscle fibers just near the electrode, excessive jitter and bocking. Incresed amplitude means focal grouping (reinnervation with sprouting, regeneration of split fibers), hypertrophy of muscle fibers. Duraion is the time between the starting-point and end-point of the slow component of the MUAP and related to number of muscle fibers within radius of $5 \mathrm{~mm}$. Reduced duration means loss of muscle fibers and increased duration indicates increased number of muscle fibers, e.g. collateral sprouting. Increased number of phases means increased slow conduction in terminal axons, and/or increased variability of muscle fiber diameter. Pathological changes in acute denervation are the appearance of non-functional motor unit, muscle fiber atrophy, and slow conduction in terminal axon branch; then polyphasic but not high amplitude and long duration MUAPs are detected. In chronic denervation, grouping and increased numbers of muscle fibers was occurred by reinnervation with sprouting are appeared; then high amplitude and long duration MUAPs are detected. In myopathy, atrophy and/or loss of muscle fibers and variation of muscle fiber diameters (compensatory hypertrophy) are the main pathological changes; then MUAPs in myopathy are low ampulitude (high amplitude MUAPs are also detected near the hypertrophic muscle fibers), short duration, and polyphasic. Evaluation of interference pattern is also very important. Loss of motor units is the main pathologial change in neuropathy even in the acute and chronic neurologenic changes. Early recruitment or pathological interference is chracteristic in myopathy. Evaluation of interference pattern is also very important. Loss of motor units is the main pathological change in neuropathy even in the acute and chronic neurologenic changes. Early recruitment or pathological interference is chracteristic in myopathy.
\end{abstract}

Key words : 筋電図 (electromyography), 同心型針電極（concentric needle EMG），運 動単位活動電位 (motor unit action potential), 神経疾患 (neuropathy), 筋疾患 (myopathy)

1999 年 8 月 31 日受稿

*市川市リハビリテーション病院リハビリテーション科/テ 272-0802 市川市柏井町 4-229-4

Department of Rehabilitation Medicine, Ichikawa Rehabilitation Hospital 


\section{はじめに}

針筋電図検査というと，一般に，その筋が異常 であるのかないのか，異常なのであればそれが神 経原性変化であるのか，筋原性変化であるのかを 診断する検査と認識されている。もちろんそれは 事実であり，極めて重要な側面である。しかし， 針筋電図から得られる情報はそれだけにはとどま らない.これらの情報を受け止めることはリハビ リテーション医学においても大いに意義のあると ころであるが，そのためにはその基礎となる生理 と筋病理を理解しておくことが不可欠である.

\section{運動単位と運動単位活動電位}

\section{1. 運動単位 (motor unit)}

運動単位は, Liddell \& Sherrington ${ }^{21)}$ により, 1つの運動ニューロンと, それが支配する筋線維 群として定義されている（図 1). 1 つの運動ニュ 一ロンが支配する筋線維数は筋の機能により異な り，外眼筋では 3〜10，第一背側骨間筋では 300 ～400, 上腕二頭筋では 700～800 とさまざまであ るが，これらは筋横断面で直径約 $5 \sim 10 \mathrm{~mm}$ 程 度の領域に散在して分布している ${ }^{20)}$ 。つまり，多 数の運動単位は重複した形で存在しており, 正常
人では隣り合った筋線維が同一の運動単位に属す ることは稀である。

1 つの運動ニューロンの発火は, その運動単位 に属するすべての筋線維の発火, 収縮を惹起し, 筋張力を発生させる. 筋収縮力の増加は, 個々の 運動単位の発射頻度の増加と, これらの運動単位 が次々と動員されることにより生じるが，その動 員順序は Henneman ら ${ }^{17)} に よ り$, 大きさの原理 (size principle) にしたがって小さい運動単位か ら始まり，順次大きな運動単位が動員される．筋 組織化学的には微小筋収縮では Type I 線維が活 動し, 強筋収縮において Type II線維が活動する とされている ${ }^{43)}$. 針筋電図においてはこれらの 個々の運動単位の活動電位を振幅, 持続時間など のパラメータ (図 2) で評価し, 複数の運動単位 活動電位の出現状況を干渉波として評価してい る.

\section{2. 運動単位活動電位 (motor unit action potential : MUAP) $)^{2,4 \sim 6,8 \sim 12)}$}

筋電図に抢いて初めて運動単位を検出したのは Adrian \& Bronk ${ }^{1)}$ であり, 以後数多くの報告が なされている. 現在では中心電極と外套との電位 差を電気信号として測定する同心型針電極がもつ とも汎用されているおり，その代表的なパラメー 夕である振幅, 持続時間, 相のもつ生理的意義と

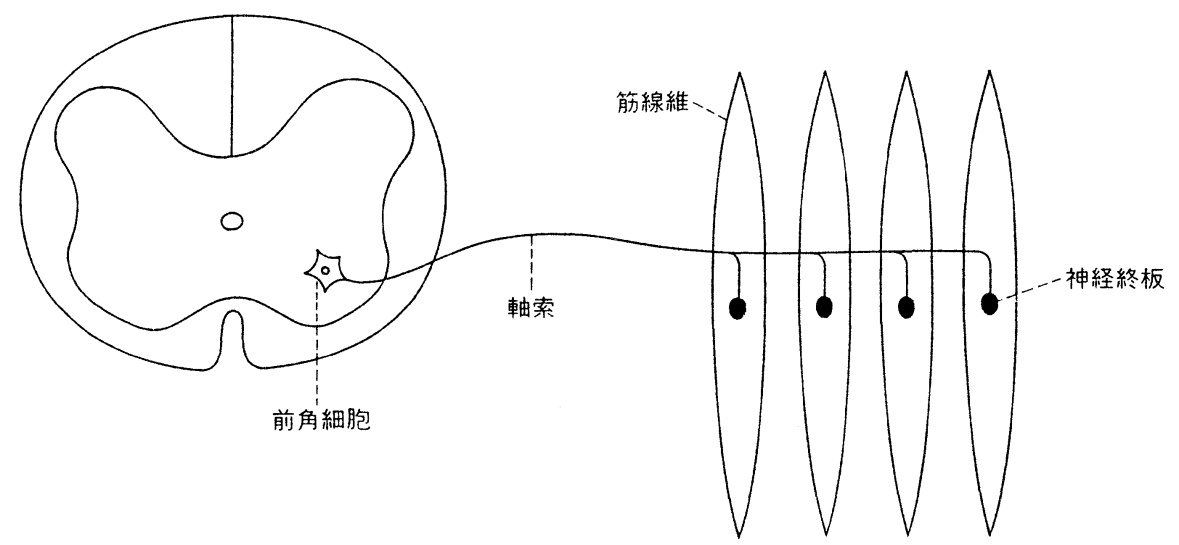

図 1 運動単位（motor unit）（文献 10 より引用）

運動単位は前角細胞（anterior horn cell）, 軸索 (axon), 神経終板（motor end plate）および その支配筋線維（muscle fibers）により構成される。 


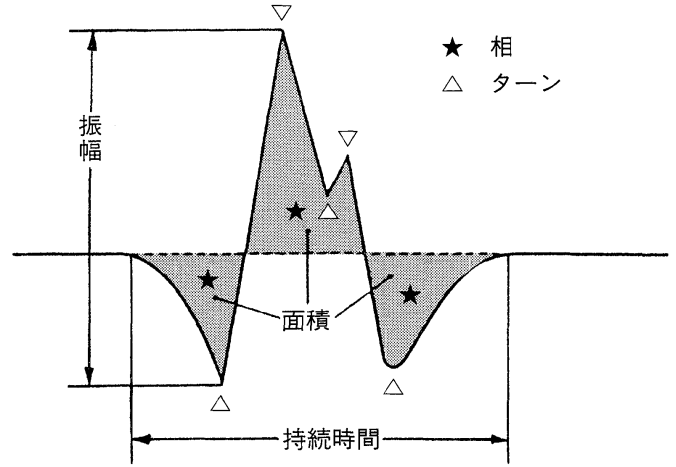

図 2 MUAP のパラメータ（文献 23 より引用, 一部 改変)

振幅は peak to peak amplitude で定義される. 持続時間 はMUAP が基線を離れてから, 最終的に基線にもどるま での時間である。面積は持続時間内での MUAP 波形と基 線に囲まれた部分の面積の総和である。相は持続時間内で の基線を通過した回数 +1 で定義される.ターンは基線の 通過の有無にかかわらず, MUAP が方向をかえる点であ り，5相以上を多相波，6ターン以上を polyturn と呼ぶ.

干渉波について述べる。

\section{a. 振幅 (amplitude)}

筋線維の活動電位を同心型針電極で記録する場 合，その振幅に最も影響する因子は活動する筋 線維と記録電極との距離である. Nandedkar $ら^{14,28,30,31)}$ はコンピューターシミュレーションに より，通常の同心針電極を使用した場合， MUAP の振幅に強く影響するのは記録電極に隣 接した筋線維であり (図 3)，200～300 $\mu \mathrm{m}$ 離れ るとその影響が $50 \%$ 程度となり，1 mm 離れる とほとんど影響がなくなることを示した。これは 針電極の位置がわずかに動くと，その MUAP の 振幅が大きく変化することを意味する，同心型針 電極は中心電極が長軸 $600 （$ まは $580 ） \times$ 短軸 $150 \mu \mathrm{m}$ の楕円形のものが汎用されているが，そ の表面積は約 $7 \times 10^{4} \mu \mathrm{m}^{2}$ であるため, 直径約 50〜 60 $\mu \mathrm{m}^{32)}$ である筋線維は $20 \sim 30$ 程度が記録 電極にごく隣接したものとなる.さらに, 運動単 位の筋線維密度から推定すると, その 20〜30 程 度の筋線維のうち同一の運動単位に属する筋線維 は通常では 2〜3 本程度となり, この筋線維の活 動電位が MUAP の振幅の形成に大きく関与する ことになる。つまり, 振幅が大きくなるというこ

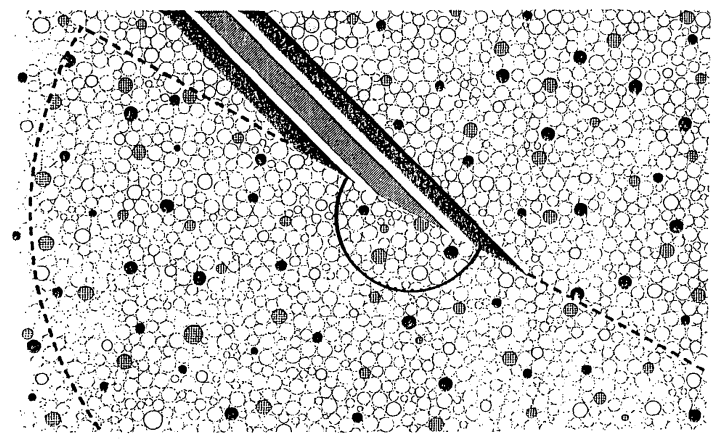

図 3 振幅，持続時間の Pick Up Area（文献 15 より 引用, 一部改変)

振幅は針電極にごく隣接した範囲の筋線維の影響をうける (実線)。持続時間は半径 $3 \sim 5 \mathrm{~mm}$ 程度の範囲に含まれる 筋線維数を反映している(破線).

とは隣接した筋線維の数が増加する, すなわち筋 線維密度が増加する，あるいはこれらの筋線維の 径が大きくなることを意味し, 振幅の減少は筋線 維密度の減少もしくは筋線維径の縮小を意味して いることになる。

\section{b. 持続時間 (duration)}

MUAP の持続時間は記録電極から半径 3 5 $\mathrm{mm}$ の範囲の電位変化に影響され，また，そこ に含まれる筋線維数にほほ比例するとされてい る. 1 つの運動単位の半径は筋により異なるが 0.5 5.0 mm 程度とされているので，持続時間 はほぼ運動単位全体の筋線維活動を反映している ことになり，また針電極の位置による影響を受け にくい.したがって持続時間の延長・短縮はその運 動単位に属する筋線維の増加・減少を意味する.

\section{c. 相 (phase)}

多相性の MUAP は，MUAPを構成する各筋 線維の発火の時間的ばらつきが原因になってい る。相は振幅と同様か, やや広い範囲での針電極 に隣接した筋線維の活動を反映しているので，多 相波の出現はこの限局した範囲での神経の伝導 性のぼらつきを示していることになる。また， Nandedkar らは，この隣接した筋線維径の大小 不同も多相波を出現させる原因になることも示し ている.

\section{d. 干渉波 (interference pattern) ${ }^{33)}$}

振幅，持続時間，相などが個々の MUAP を評 
価するものであるのに対し，干渉波は複数の運動 単位の動員状況を評価するものである．筋張力の 増加は, 個々の運動単位の発射頻度の増加と, 運 動単位の動員により生じるが，この動員により針 筋電図上複数の MUAP が観察されるようにな る.ひいてはこれらの MUAP が重なって観察さ れるようになり，個々の MUAP の同定が不能と なり，干渉波と呼ばれる。

この動員状況を定性的に（あるいは半定量的 に）評価することが干渉波の評価である。干渉波 の減少とは筋収縮力を増加させても, MUAP の 発射頻度が増加するのみで新しい MUAP が動員 されてこない，または少数しか動員されない状態 である。これは運動単位が減少していることを意 味する。この状態は loss of motor unit，または decreased recruitmentと呼ばれる。また, 病的 干渉 (pathological interference), つまり, 微 小収縮においても個々の MUAP が同定困難なほ ど多数の運動単位が動員される状態, は個々の運 動単位の筋出力が低下していることを意味する。 この状態では筋収縮力に比して次々と運動単位が 動員されてくるので early recruitment とも呼ば れている。

\section{神経原性変化, 筋原性変化と 筋電図所見 ${ }^{23,35,38,39)}$}

\section{1. 神経原性変化（図 4)}

\section{a. 初 期}

神経原性変化によりまず第一に生じることは, 機能を停止した運動単位の出現である。つまり運 動ニューロンが発火しなくなる，または発火して も伝導しなくなることにより，その運動ニューロ ンが支配する筋線維の発火・収縮が起こらない運 動単位が出現するという状態である。この状態で 針筋電図検査を施行すると，まだ自発電位（陽性 鋭波（positive sharp wave）や筋線維攣縮 (fibrillation potential)) や，観察される個々の MUAP の変化は認められず，筋収縮力を強めて も（強めようとしても）運動単位が少数しか（ま たは全く）動員されてこない，すなわち干渉波の
(1)

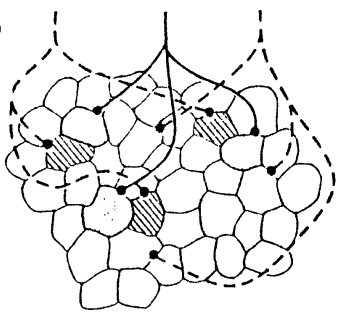

(2)

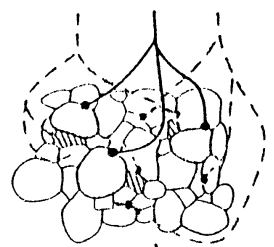

(3)

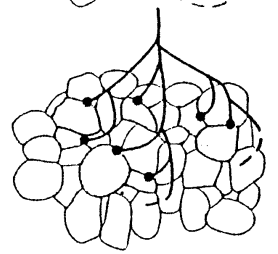

(4)

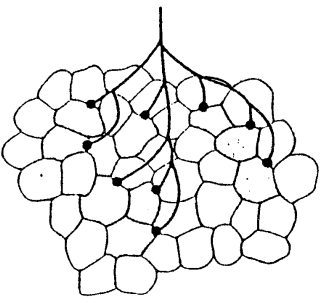

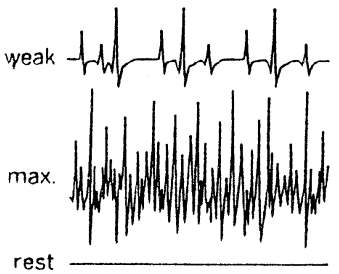
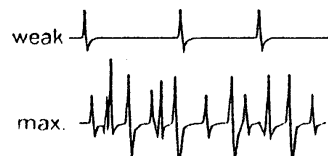

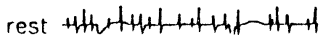

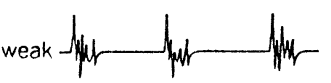

rest thrththet

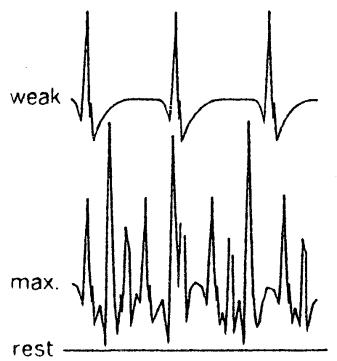

図 4 神経原性変化と筋電図所見（文献 35 上り引用, 一部改変)

(1)正常: 弱収縮では 3 つの運動単位が活動しており, 強収 縮では強い干渉波となり個々の MUAP は同定できない。 安静時筋活動は認められない. (2)脱神経早期：正常時弱収 縮で活動していた 3 つの運動単位のうち，2つが脱神経に 陥った状態の模式図. 脱神経に陥った筋は萎縮し, 自発電 位が出現する.1つ残された運動単位の MUAP は変化を 認めないが，強収縮下でも動員される運動単位は減少して

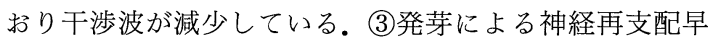
期：発芽による側枝の髄鞘化が不十分であり，多相性の MUAP が出現する. 自発電位は減少しつつある. (4)発芽 による神経再支配完成期：発芽による神経再支配が完成す ると筋線維密度が増加し, 支配筋線維数も増加するため, 高振幅，長持続時間の MUAPが出現する. 自発電位は消 失するが，強収縮下でも動員される運動単位は減少してお り干渉波が減少したままである.

減少が認められるのみである.

\section{b. 脱神経早期 (acute denervation)}

運動ニューロンの障害により，筋線維が脱神経 の状態（denervated fiber）に陥ると，笳線維は 
萎縮する。このとき膜電位は不安定となり，個々 の筋線維の自発発火が見られるようになる。これ が陽性鋭波，筋線維攣縮などの自発電位であり， 症状に遅れること 10～14 日程度で出現する。こ れらの脱神経がすべての運動単位に及んだ場合は 運動単位が動員されず，当然 MUAP は観察され ないが，障害が部分的（partial denervation）で あれば，急性期でも MUAP が観察される。この 場合, 動員されている個々の運動単位は正常であ るため，各々の MUAP の振幅，持続時間，相な どは変化しないが, 動員される運動単位数は減少 しており，干渉波の減少は引き続き認められる。

\section{c. 神経再支配早期}

i ) 神経発芽 (sprouting) による神経再支配 運動ニューロンそのものの障害または軸索の重 度の障害などにより萎縮に陥った筋線維には，他 の残存した運動単位の筋内神経軸索からの神経発 芽により萎縮した筋線維の神経再支配（reinnervation）が起こる。この再支配の早期には発芽に よる側枝の髄鞘化が不十分であるため伝導速度が 遅く，またブロックも生じやすい。そのため多相 性の MUAP が出現し，1回ごとの MUAP の形 が変化する Jiggle 現象が見られる。この運動単 位は以前より筋線維密度が増加し，また多くの筋 線維を支配するようになるため，再支配が進むに つれ MUAP の振幅，持続時間が増大する（いわ ゆる neuropathic unit).しかし，これらの再支 配が進んでも運動単位の数は回復しないため, 干 渉波は減少している。

ii）もとの運動ニューロンからの神経再支配

軸索遮断（axonotmesis）後の神経再支配は, 本来その筋線維が属していた運動ニューロンから の再支配を受ける場合が多い。この場合も早期に は再支配神経の髄鞘化が不十分であるため多相性 の MUAP の出現や Jiggle 現象が認められる. しかし，発芽と異なり筋線維密度は増加せず，筋 線維が萎縮しているため振幅はむしろ小さくな る。また支配筋線維数も増加するわけではなく， 早期にはむしろ減少しているため持続時間も短い MUAP が出現する（以前は nascent unit と呼ば れていた). 運動単位の数は回復しつつあり干涉
波の減少は認められなくなる。

このように自発電位の出現とともに神経再支配 が進行しつつある状態は active denervationも しくは active neurogenic change と呼ばれる.

\section{d. 神経再支配完成期}

i ）神経発芽による神経再支配

側枝が十分発育するとその伝導性が回復するた め多相性の MUAP が減少する。また筋萎縮が回 復し, 筋線維密度が増加, 支配筋線維数も増加す るため, 単相性, 高振幅, 長持続時間の MUAP （いわゆる giant unit）が出現する. 運動単位数 は減少しているので干渉波は減少している。また 再支配により denervated fiber が消失すれば自発 電位も検出されなくなる。このような状態は inactive denervationまたは inactive neurogenic change と呼ばれる。

ii）もとの運動ニューロンからの神経再支配

この再支配が完成すると個々の運動単位の筋線 維密度，筋線維径および支配筋線維数はほぼもと どおりに回復することになる。また運動単位の数 も正常である。したがって個々の MUAP も干渉 波も正常化する。

神経疾患が疑われる症例に対し針筋電図検査を 行う場合には，その診断とともに，その症例が現 在どのような病態にあるのかを診断することが重 要である，例えば発症後一定期間を経過しても， 自発電位とともに神経再支配の早期を示す多相性 で，さほど高振幅ではない MUAP が中心となっ ている場合は，発芽による神経再支配が追いつか ないほど脱神経が進行していることを示す。これ らの所見は急速進行性の筋萎縮性側索硬化症など に認められ予後不良である。一方，慢性的に穏徐 に進行する神経疾患（春髄性進行性筋萎縮症, 遺 伝性末梢神経炎の一部や頸椎症など）や過去に起 こった脱神経のエピソードから十分に時間が経過 した場合（ポリオや外傷など）は十分に神経再支 配が完成した inactive denervationの状態とな り，筋電図では，いわゆる giant unit が出現して いる，運動単位数は減少しており，特に残された 運動単位がごく少数の場合は 1 つの運動単位の消 失により急激な筋力低下をきたすことになる，長 
期間経過中の頸椎症患者にみられる急激な上肢筋 力の低下や，いわゆるポストポリオ症候群などは このようなメカニズムが関与していると考えられ る.

\section{2. 筋原性変化 ${ }^{28,29,35)}$ (図 5)}

筋原性変化の基本的な病理学的変化は神経支配 とは無関係な筋線維の変性, 萎縮, 壊死である. したがって各運動単位に属する筋線維の数は減少 し, 筋線維密度も低下, 筋線維径も縮小する。し たがって，各運動単位の MUAP の持続時間は短 縮，振幅は低下する。また，個々の運動単位の筋 出力が低下しているため, 微小筋出力を発生させ るためにも多くの運動単位を動員する必要があ り，微小収縮においても多数の MUAP が干渉波 として観察される。この現象は early recruitment, もしくは病的干涉 (pathological interference）と呼ばれ，筋原性変化におけるもっとも 重要な特徴である。

また, 多くの筋原性疾患は壊死ともに再生過程 を伴う，筋線維の分節的な壊死は，筋線維を断裂 させ，神経終板のついていない脱神経された筋線 維を出現させる。これらの筋線維は陽性鋭波や筋 線維攣縮などの自発電位を発するとともに，脱神
経筋として神経再支配を受けるが，その過程は神 経疾患の場合と同様であり, 針筋電図では多相波 となる。また残存した筋線維は代償性に肥大寸る ものもあり，この近傍に針電極が刺入されれば高 振幅の MUAP が検出されることになる。またこ の代償性肥大と萎縮による筋線維の大小不同は多 相波を出現させる.しかし，いずれの場合も各運 動単位に属する筋線維数は減少しており, 持続時 間は短縮している。

\section{筋電図診断上のおとし穴（pitfalls）}

\section{1. 自 発電位}

陽性鋭波および筋線維攣縮は神経疾患で認めら れることが多いことから, “脱神経電位 (denervation potential)”と呼ばれてきた。これらは障 害された個々の筇線維が抢そらく筋細胞膜の変化 により，自発的にもしくは刺激にひきつづき反復 的に発火するものである。“脱神経電位”という 名称から神経原性変化に特有のものと誤解されが ちであるが，前述のように神経疾患でもごく早期 や inactive denervation では認められず，筋疾患 でも高率に出現する。また，脳血管障害による片 麻痺患者の患側上肢遠位筋にも自発電位は高率に
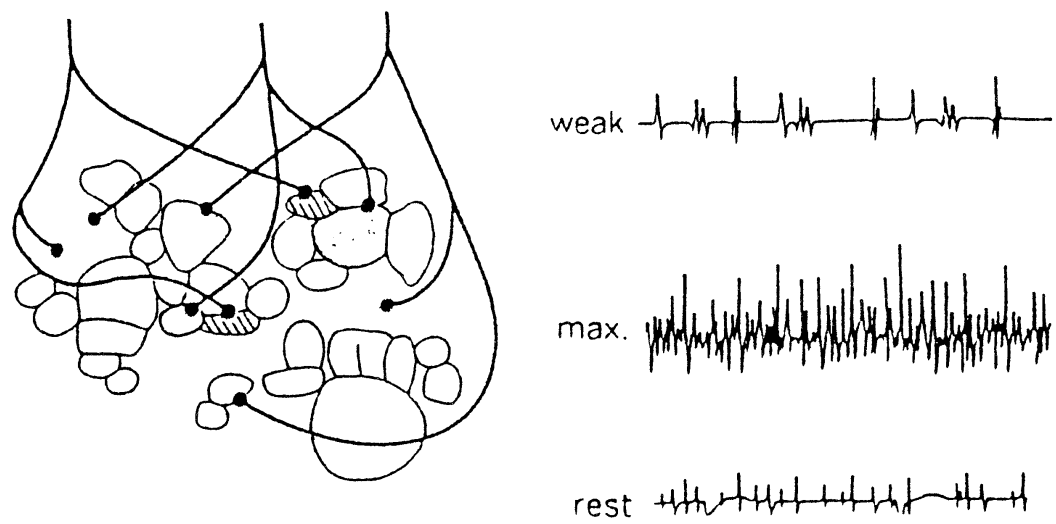

図 5 筋原性変化と筋電図所見（文献 35 より引用，一部改変）

運動単位とは無関係に筋線維の萎縮と代償性肥大がみられる。個々の運動単位の筋収 縮力が低下しているため, 微小収縮においても多数の MUAP が出現する. 個々の MUAP の振幅は小さく，多相性で持続時間は短いものが多いが，肥大した筋線維に隣 接して針電極を刺入すると高振幅の MUAP が検出される。安静時には自発電位が認め られる場合が多い. 強収縮に至る前に多くの MUAP が干渉波として観察され, 病的干 渉と呼ばれる. 
出現し, transsynaptic denervation として説明 されている。

\section{MUAP パラメータの限界}

かつて高振幅長持続時間の MUAP は “神経原 性波形 (neuropathic unit)”，低振幅短持続時間 の MUAP は “筋原性波形 (myopathic unit)” と呼ばれたことがあった。これらは確かに神経原 性変化もしくは筋原性変化の一側面ではあるが, いままで述べてきた病期や病理学的変化を念頭に おいてその波形のもつ意味を考慮する必要があ る.

個々の運動単位に属する筋線維数を反映する持 続時間は, 理論的にはその運動単位の筋線維数が 増加もしくは正常である神経疾患と筋線維数が減 少する筋疾患を区別できると期待される。しかし 持続時間の測定には十分平坦な基線が必要なこ と，かつ持続時間の終了をどこにするかの判断が むずかしいこと，また持続時間はアンプのゲイン に依存するため同じゲインで測定した MUAPし か比較できないこと, などのため定量的な判断は むずかしい. また，苦心して正確に測定しても， 神経疾患と正常例の持続時間の平均值は大きく才 ーバーラップしており，必ずしもその弁別性は高

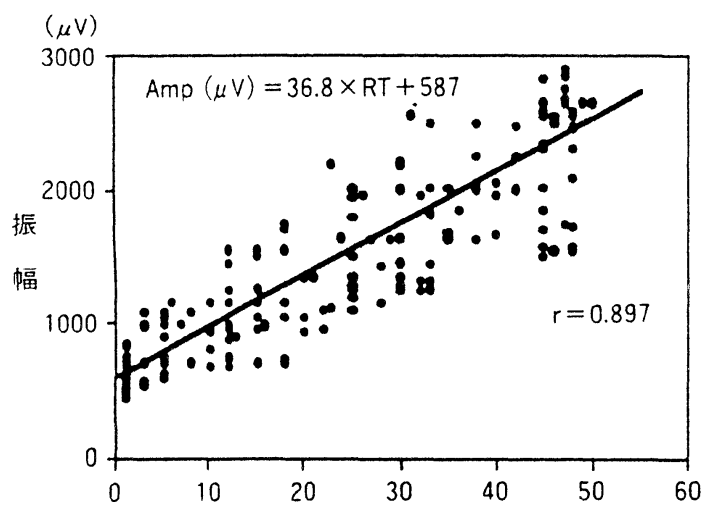

くはない.

園生ら ${ }^{36,37)}$ は正常と神経原性変化を高率に区 別できるパラメータとして size index (size index $=2 \log \operatorname{Amp}(\mathrm{mV})+\operatorname{Area} / \operatorname{amp}(\mathrm{msec}))$ を提唱している. Size index は針電極の位置に 左右されず, inactive denervationの際の MUAP と正常 MUAP の区別に有用であるが, active denervation や筋疾患と正常との区別は困 難である。

\section{3. 筋収縮力と筋電図 ${ }^{3,7,12,13,15,16,22,24 ~ 27)}$}

筋収縮力の増加は, 個々の運動単位の発射頻度 の増加と, 運動単位の動員により生じるが, その 動員順序は大きさの原理にしたがって順次大きな 運動単位一支配筋線維数が多く，その筋線維径も 大きいーが動員される.すなわち筋収縮力を強め ると正常人でも高振幅で持続時間が長い MUAP が出現することになる(図6)。高振幅長持続時 間の MUAP が他の MUAP に先駆け, 第一に動 員されたのであれば, inactive denervation が示 唆されるが，小さな MUAP に引き続き，強収縮 力のもとで動員されたのであれば病的意義は乏し い.

干渉波の評価においてはさらにその筋収縮力を

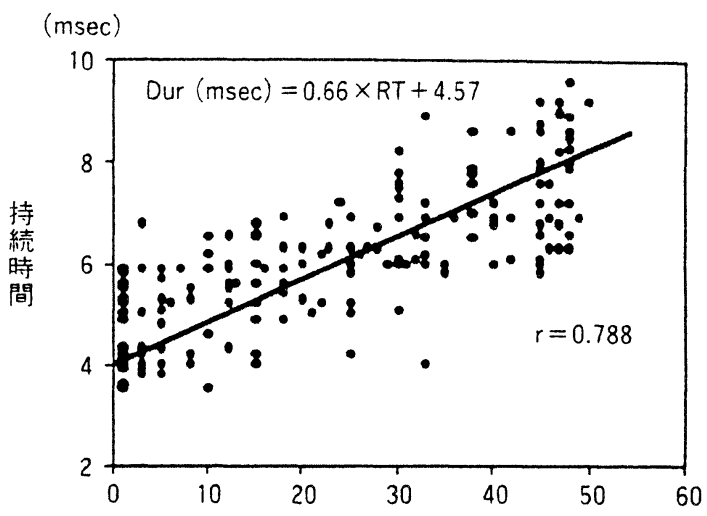

動員閾値 (\%MVC )

図 6 第一背側骨間筋にお㧈ける MUAP の動員閾値と振幅，持続時間との関係（文献 3 より引用） 筋収縮力を徐々に強めながら, 動員されてくるMUAP 観察すると, 動員閾値*が大きくなるにつれ, その振幅は大き く, 持続時間は長くなる. Amp: Amplitude, Dur: Duration, RT : Recruitment Threshold, MVC: Maximal Voluntary Contraction. *その MUAPがはじめて観察されたときの筋収縮力。ここでは最大随意筋収縮力（MVC）に対する比 (\%MVC) で示されている. 
念頭におくことが重要である。“干渉波の減少” といっても, 被検者が疼痛などにより十分な筋収 縮を行うことができなければ，干渉波が減少して いることは当然である。干渉波の評価は最大収縮 下で行うことが原則であるが，被検者の筋収縮力 を確認しつつ，「これぐらいの筋収縮力では，こ の程度の運動単位が動員されていればほほ正常」 「この筋収縮力でこの動員運動単位数は異常」な どと定性的に判断していくことも重要である. 堀 田ら ${ }^{19)}$ は，神経疾患患者では正常人よりも同筋 収縮力での動員運動単位数が少ないことを定量的 に示している.

現在，定量的筋電図 ${ }^{18,34,40,41)}$ として MUAP を コンピュータで自動的に同定し，そのパラメータ をもって診断を行うという試みがなされており， そのプログラムが装備されている筋電計もある。 しかし MUAP パラメータのみを重視するのは危 険であり，必ず運動単位の動員状況や筋収縮力， 自発電位そして臨床症状と組み合わせて，その病 態を推測し，診断を行っていく必要がある.

\section{結 語}

以上，針筋電図における生理と臨床について述 べてきたが，重要なことは，「こういう所見があ るから神経原性変化である」と考えるのでなく， 「こういう所見はこのような病態である。したが って神経原性（あるいは筋原性）変化の，このよ うな病期，病態と合致する」という思考である。 これはリハビリテーション医学においても重要で ある。たとえば末梢神経障害に対する電気刺激な どのリハビリテーションの適応も active denervation と inactive denervation では区別して検 討する必要があるであろう。また，その機能回復 に関しても，神経発芽による神経再支配が進行し ている場合と早期より多数の運動単位が出現して いる場合では最終的な回復状況が異なることが推 測できるであろう。

針筋電図は強い疼痛を伴う検査である。したが ってそこから読み取る情報が検者により大きく異 なるのでは問題がある，筋電図に携わる者は，そ
こから少しでも多くの情報を読み取ることができ るように努力していかねばならない.

\section{文献}

1) Adrian ED, Bronk DW : The discharge of impules in motor nerve fibers, Prat 2. The frequency of discharge in reflex and voluntary contractions. J Physiol 1929; 67 : 119-151

2）赤星和人, 正門由久, 千野直一：運動単位の動員閾値 と振幅との関係. 臨床脳波 $1994 ; \mathbf{3 6}:$ 349-353

3）赤星和人：運動単位活動電位の振幅ならびに持続時間 に関する基礎的研究. リ八医学 1996；33：167-175

4) Appenberg B, Emonent-Denand F : Motor units of the first superficial lumbrical muscle of the cat. J Nuerophysiol 1967; 30 : 154-160

5) Basmajian JV : Control of individual motor units. Am J Phys Med 1967 ; 46 : 480-486

6) Basmajian JV : Electromyography comes of age. Science $1972 ; \mathbf{1 7 6}:$ 603-604

7) Basmajian JV, De Luca CJ (ed) : Muscles Alive. 5th Ed, Williams \& Wilkins, Baltimore, 1985; pp 187-200

8) Bischoff C, Stålberg E, Falck B, Edelbol EegOlofsson $\mathrm{K}$ : Reference values of motor unit action potentials obtained with multi-MUAP analysis. Muscle Nerve $1994 ; 17: 842-851$

9) Buchthal $\mathrm{F}$ : The general concepts of motor unit. Res Publ Ass Nerv Dis 1961; 38: 1-30

10）千野直一: 臨床筋電図・電気生理学入門. 第 3 版, 医 学書院, 東京, 1997

11) De Luca CJ, Lefever RS, McCue MP, Xenakis AP : Controls scheme govering concurrently active human motor units during voluntary contractions. J Physiol 1982; 329: 129-142

12) De Luca CJ : Control properties of motor units. in Computer-aided Electromyography and Expert Systems (ed by Desmedt JE). Elsevier, New York, 1989 ; pp 103-113

13) Dorfman LJ, Howard EJ, McGill KC: Influence of contractile force on properties of motor unit action potentials: ADEMG analysis. J Neurol Sci 1988; 86 : $125-136$

14) Ekstedt J, Stålberg E: How the size of the needle electrode leading-off surface influences the shape of the single muscle fibre action potential in electromyography. Computer Prog Biomed 1973; 3: 204-212

15) Ertas M, Stålberg E, Falck B : Can the size principle be detected in conventional EMG recordings? Muscle Nerve 1995 ; 18 : 435-439

16) Hakansson $\mathrm{CH}$ : The propagation velocity of isolated frog muscle fibers. Acta Physiol Scand 1954; 31: $22-23$

17) Henneman E, Somjen G, Carpenter DC : Functional significance of cell size in spinal motoneurons. J Neurophysiol $1965 ; 28: 560-580$ 
18）廣瀬和彦：運動単位電位解析の最近の動向. 脳波と筋 電図 1997 ; 25 : 353-361

19）堀田富士子, 道免和久, 赤星和人, 正門由久, 木村彰男, 千野直一：臨床針筋電図における運動単位の動員と筋 収縮力に関する検討. 脳波と筋電図 $1998 ; 26 ： 145$

20) Kimura J : Electrodiagnosis in Disease of Nerve and Muscle: Principles and Practice. FA Davis, Philadelphia, 1983 ; pp 243-244

21) Liddell ET, Sherrington CS: Recruit and some other features of reflex inhibition. Proc $\mathrm{R}$ Soc London 1925 ; 97 : 488-518

22）正門由久: 運動単位の発射様式に関する基礎的研究一 単一運動と複合運動との比較一.リ八医学 $1991 ; 28$ ： 703-712

23）正門由久：針筋電図. 臨床リハ $1999 ； 5$ : 430-434

24) Masakado $Y$, Noda $Y$, Nagata M, Kimura A, Chino $\mathrm{N}$, Akaboshi $\mathrm{K}$ : Macro-EMG and motor unit recruitment threshold: differences between young and the aged. Neurosci Lett $1994 ; 179: 1-4$

25) Masakado $Y$, Noda $Y$, Nagata M, Kimura A, Chino $\mathrm{N}$, Akaboshi K: Macro-EMG and motor unit recruitment threshold. Muscle Nerve 1993; 16: 987-988

26) Masakado $Y$, Akaboshi K, Nagata M, Kimura A, Chino $\mathrm{N}$ : Motor unit firing behavior in slow and fast contractions of the first dorsal interosseous muscles of healthy men. Electroencephalogr Clin Neurophysiol $1995 ; 97$ : 290-295

27) Milner-Brown HS, Stein RB : The relation between the surface electromyogram and muscular force. J Physiol 1975 ; 246 : 549-569

28) Nandedkar SD, Sanders DB, Stålberg EV, Andreassen S: Simulation of concentric needle EMG motor unit action potentiàls. Muscle Nerve 1988; 11: 151-159

29) Nandedkar SD, Sanders DB: Simulation of myopathic motor unit action potentials. Muscle Nerve 1989 ; 12 : 197-202

30) Nandedkar SD, Sanders DB : Principal component analysis of the features of concentric needle EMG motor unit action potentials. Muscle Nerve 1989; 12: 288-293

31) Nandedkar SD, Barkhaus PE, Sanders DB, Stålberg $\mathrm{EV}$ : Analysis of amplitude and area of concentric needle EMG motor unit action potentials. Elactroencephalogr Clin Neurophysiol 1998; 69: 561-567

32) Polgar J, Johnson MA, Weightman D, Appleton D : Data on fibre size in thirty-six human muscles in autopsy study. J Neurol Sci 1973 ; 19 : 307-318

33) Sanders DB, Stålberg EV, Nandedkar SD : Analysis of the electromyographic interferrence pattern. J Clin Neurophysiol 1996: 13:385-400

34) Sanders DB, Nandedkar SD, Barkhaus PE: Multimotor unit action potential analysis (MMA). Muscle Nerve 1995; 18 : 1155-1166

35）園生雅弘：筋電図と笳病理. 病理と臨床 1993 ；11 : 1256-1261

36）園生雅弘：運動単位電位諸パラメーターの意義と有用 性. 臨床脳波 $1994 ； 36$ : 358-362

37) Sonoo M, Stålberg E: The ability of MUP parameters to discriminate between normal and neurogenic MUPs in concentric EMG: analysis of the MUP "thickness" and the proposal of "size index". Elecroencephalogr Clin Neurophysiol 1993; 89: 291-303

38) Stålberg E, Trontelj JV : Single Fiber Electromyography Studies in Healthy and Diseased Muscle. 2nd Ed, Raven Press, New York, 1994

39) Stålberg E: Electrodiagnostic assessment and monitoring of motor unit changes in disease. Muscle Nerve $1991 ; \mathbf{1 4}: 293-303$

40) Stålberg E : Multi-MUP analysis - two year experience in daily clinical work. Electroencephalagr Clin Neurophysiol $1995 ; 97$ : 145-154

41) Stashunk D, De Luca CJ : Update on the decomposition and analysis of EMG signals. in Computeraided Electromyography and Expert System (ed by Desmedt JE). Clin Neurophysiol Updates 2, Elsevier New York, 1989 ; pp 39-53

42) Uncini A, Lange DJ, Lovelace RE: Long duration poliphasic motor unit potentials in myopathies: a quantitative study with pathological correlation. Muscle Nerve $1990 ; 13$ : 263-267

43) Warmolts JR, Engel, WK: Open-biopsy electromyography-correlation of motor unit behavior with histochemical muscle fiber type in human limb muscle. Arch Neurol 1972; 27 : 512-517 